Jurnal Konstruksi Hukum | ISSN: XXXX | E-ISSN: XXXX Vol. 1, No. 1, September 2020 Hal. 187-191| Available online at https://www.ejournal.warmadewa.ac.id/index.php/jukonhum

DOI: https://doi.org/10.22225/jkh.1.1.2155.187-191

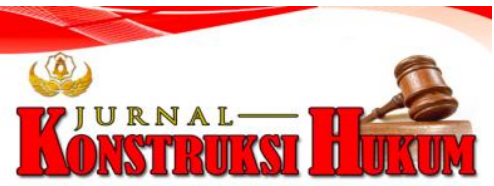

\title{
PENGESAHAN AWIG-AWIG DESA ADAT BERDASARKAN PERATURAN DAERAH NOMOR 4 TAHUN 2019
}

\author{
I Gusti Ayu Mas Mahadewi, I Ketut Sukadana, Luh Putu Suryani \\ Fakultas Hukum Universitas Warmadewa, Denpasar-Bali, Indonesia
}

\begin{abstract}
Abstrak
Awig-awig adalah suatu aturan sendiri yang dapat dibuat oleh Desa Adat dalam menjalankan pemerintahannya. Dalam penerapan Tri Hita Karana Awig-Awig yang dibuat oleh krama desa adat/banjar adat digunakan sebagai pedoman dalam menjalankan ajaran Tri Hita Karana yang harus sesuai dengan dharma agama dan desa mawacara di desa adat setempat. Dalam penulisan Awig-Awig memerlukan berbagai proses dan tidak asal jadi. Penelitian ini bertujuan untuk mengetahui mekanisme penulisan Awig-Awig dan bagaimanakah proses pengesahan Awig-Awig berdasarkan peraturan daerah nomor 4 tahun 2019. Metode yang digunakan dalam penelitian ini adalah metode penelitian hukum normatif yang menggunakan pendekatan konseptual dan pendekatan kasus. Tahap pertama dari mekanisme penulisan awig-awig ini dimulai dari merivisi Awig-Awig yang telah ada dan agenda penulisan awig-awig. Kemudian, tahapan kedua meliputi penulisan rancangan AwigAwig. Setelah itu, sosialisasi rancangan awig-awig. Keempat, penyelesaian penulisan Awig-Awig. Proses terakhir dalam paruman desa adat diadakan pengesahan dan kemudian awig-awig tersebut diumukan secara terbuka dalam kepada seluruh krama desa adat selanjutnya awig-awig yang sudah tersurat didafttarkan langsung oleh Prajuru Desa Adat ke perangkat daerah provinsi yang membidangi urusan desa adat.
\end{abstract}

Kata Kunci: Desa adat; Mekanisme penulisan Awig-Awig; Pengesahan awig-awig

\begin{abstract}
Awig-awig is a customary village regulation that can be made in running its government. In the application of the Tri Hita Karana Awig-Awig which is made by the customary village krama / traditional banjar, it is used as a new way to carry out the Tri Hita Karana teachings which must be in accordance with the dharma of religion and the village of mawacara in the local traditional village. In the Awig-Awig task, it requires various processes and is not arbitrary. This research aims to study Awig-Awig and how the process is carried out by Awig-Awig based on regional regulation number 4 of 2019. The method used in this research is a normative legal research method that uses a conceptual approach and a case approach. The first stage of this initial awigawig step starts from revising existing Awig-Awig and moving awig-awig agenda. Then, the next stage is involved in making the Awig-Awig design. After that, the socialization of the awig-awig design. Fourth, the process of completed the Awig-Awig. The last process in the traditional village paruman was legalized and then the awig-awig was announced openly to all the traditional village krama, then the awig-awig that had been written was registered directly by the Prajuru of the Traditional Village to the provincial apparatus in charge of customary village affairs.
\end{abstract}

Keywords: Traditional Village; Awig-awig mechanism; Awig-awig attestation

\section{PENDAHULUAN}

Desa adalah suatu organisasi ataupun susunan pemerintahan terkecil yang dimana desa lebih dekat dengan masyarakat. Desa adat sendiri telah diakui oleh Pemerintah Pusat. Dengan diakuinya keberadaannya, desa adat berwenang mengatur dan mengurus urusan pemerinatahn dan keperluan masyarakat (Sirtha, 2008). Di bali sendiri dikenal terdapat dua bentuk desa, yaitu desa adat dan desa dinas dimana desa adat dulu lebih dikenal dengan sebutan desa pakrama (Sanjaya \& Sugiartha, 2013). Desa adat merupakan kesatuan masyarakat yang ada, tumbuh, serta berkembang di Bali dan memiliki unsur tradisional. Menurut peraturan daerah nomor 4 tahun 2019 desa adat adalah kesatuan masyarakat hindu di bali yang memilki aturan-aturan mengenai tata krama pergaulan hidup masyarakat hindu yang berpedoman pada Tri Hita Karana. Desa dinas sendiri lebih dkenal sebagai suatu kelompok masyarakat yang secara sistematis yang berhubungan dengan tugas pemerintah pusat (Parimartha, 2013). 
Keberadaan desa adat sendiri tidak lepas dari ajaran agama hindu yang dijadikan landasan ataupun filosofi yang berpedoman pada Tri Hita Karana (Purana, 2016). Karakter dari filosofi ini sendirilah yang membedakan desa adat yang ada di Bali dengan kesatuan masyarakat hukum adat yang ada diluar Bali (Wiryawan et al., 2015). Menurut V.E.Korn desa adata ialah desa yang mempunyai adat atau hukum yang menjadi acuan masyarakat setempat. Perkembangan selanjutnya muncul istilah otonomi desa adat dimana desa adat dapat mengatur dan mengurus pemerintahannya sendiri tanpa campur tangan pemerintah pusat. Otonomi berasal dari bahasa latin, autos dan nomor yang memilki arti sendiri dan aturan. Jadi otonomi sendiri dapat diartikan suatu hak dan kewajiban dalam mengatur maupun mengurus rumah tanggan sendiri sesuai dengan kebijaksanaan (Nadir, 2013).

Dalam mengatur pemerintahannya desa adat membentuk aturannya sendiri berdasarkan kebiasaan dan ketentuan adat yang berbentuk sima, dresta yang tercatatkan dalam awig-awig dan pararem (Ida Bagus Nyoman Gandi Aditya et al., 2017). Dalam menjalankan pemerintahannya desa adat dapat membuat aturannya sendiri yang disebut awig-awig. Awig-awig berarti patokan maupun aturan bertingkah laku yang telah dibuat oleh krama desa adat atau masyarakat berdasarkan rasa keselarasan dan rasa keadilan yang tumbuh dan berkembang dalam masyarakat setempat (Astiti, 2005). Sebelum awig-awig dikenal istilah yang biasa digunakan adalah pangeling-eling, paswara, geguat, pararem, dresta, gama, tunggul, palakerta, cara, sima, kerta (Sudantra \& dkk, 2011). Kebiasaan desa adat dalam menuliskan awig-awig nya dalam bentuk sistemmatika yang beragam dimulai sejak tahun 1969. Awig-awig di bali sendiri mulai dikenal sejak tahun 1986.

Ada beberapa hierarki yang perlu dilalui dalam penyusunan awig-awig yang pertama adalah tahap persiapan, tahap penulisan, tahap sosialisasi, dan tahap penyelesaian penulisan awig-awig. Awig-awig sendiri ada yang tertulis maupun tidak tertulis, awig-awig yang tertulis pada umumnya hanya memuat aturan pokok mengenai kehidupan bermasyarakat dalam desa adat tersebut. Berdasarkan uraian di atas, maka penelitian ini bertujuan untuk mengetahui mekanisme penulisan Awig-Awig berdasarkan Peraturan Daerah Nomor 4 Tahun 2019, serta bagaimana proses penulisan Awig-Awig berdasarkan Peraturan Daerah Nomor 4 Tahun 2019.

\section{METODE PENELITIAN}

Penelitian ini menggunakan jenis penelitian hukum normatif yang dilakukan dengan studi kepustakaan yaitu berupa bahan-bahan hukum. Sesuai dengan penelitian hukum yang digunakan yaitu normatif maka pendekatan masalah yang digunakan dalam penelitian ini adalah pendekatan perundang-undangan, pendekatan konseptual. Beberapa sumber bahan hukum yang digunakan dalam penelitian ini berupa: bahan hukum primer yaitu bahan hukum yang terdiri dari perundang-undangan. Berikutnya, bahan hukum sekunder yaitu bahan hukum s diperoleh dari pengkajian kepustakaan dengan cara membaca berbagai buku hukum, jurnal hukum, dan juga informasi elektronik yang berkaitan dengan permasalahan yang dibahas dalam penelitian ini. Teknik pengumpulan bahan hukum yang digunakan dalam penelitian ini berupa teknik studi dokumentasi, pencatatan, atau mengulas informasi baik dalam buku hukum maupun media internet yang berkaitan dengan permasalahan dalam penelitian ini. Analisis data dilakukan apabila seluruh bahan hukum yang dibutuhkan sudah terkumpul, kemudian dilakukan penafsiran atau diiinterpretasi secara sistematis dan terstruktur dengan memberikan argument serta solusi terhadap mekanisme penulisan dan proses pengesahan yang disimpulkan dan semuanya dituangkan ke hasil penelitian.

\section{HASIL DAN PEMBAHASAN}

\section{Mekanisme Penulisan Awig-Awig Berdasarkan Peraturan Daerah Nomor 4 Tahun 2019}

Organisasi yang ada di Bali salah satunya desa adat sedang melaksnakan usaha dalam penulisan awig-awigyang berarti menulis awig-awig yang sudah ada dapat diartikan juga sebagai penulisan awig-awig, merevisi awig-awig juga termasuk dalam proses penulisan awig-awig. Desa adat dan awig-awig sendiri merupakan satu kesatuan yang tidak dapat dipisahkan. Pada masa Mpu Kuturan disebutkan bahwa di Bali sendiri terdapat organisasi desa yang teratur.

Pada seminar awig-awig I yang diadakan oleh Fakultas Hukum yang berkejasama Pemerintah Daerah Provinsi dijelaskan bahwa proses penulisan awig-awig ini dimulai pada tahun 1969. Diadakannya seminar ini memiliki tujuan untuk mengetahui tatanan awig-awig dalam 
kehidupan bermasyarakatdan juga untuk mengetahui landasan berlakunya awig-awig. Seminar ini merupakan tongak terpenting dalam mekanisme maupun proses penulisan awig-awig. Perkembangan budaya dari setiap masyarakat desa membentuk banyak variasi bentuk, isi dan sanksi-sanksi yang ada dalam awig-awig. Seminar awig-awig I ini menghasilkan rekomendasi berupa pedoman yang menjadi acuan dalam penulisan awig-awig, dimana Pancasila, UUD 1945, dan Tri Hita Karanadalam penulisan awig-awig sebagai dasar sekalaniskala sebagai tujuan. Dari seminar tersebut, ada beberapa cara dalam penulisan awig-awig, yaitu: mengadakan rapat bagi krama desa setempat untuk mengenali apa saja masalah dan bahan apa saja yang diperlukan dalam penulisan. Kemudian, membentuk panitia yang biasa disebut panitia kecil terdiri dari pemuka masyarakat yang bertugas untuk menyusun dan menginterpretasikan segala permasalahan. Jika diperlukan panitia kecil dapat di damping oleh tim dari Pemerintah Daerah. Dalam parumankrama desa adat setempat konsep awig-awig yang diajukan bertujuan untuk mendapatkan pengkajian sampai diperoleh keputusan dari seluruk krama. Selanjutnya, dalam pembuatan konsep awig-awig panitia kecil perlu mengadakan pembagian tugas.

Setelah awig-awig selesai di buat maka tahapan yang terakhir adalah pengesahan yang dilakukan dalam paruman desa adat yang diselenggarakan oleh krama desa setempat, kemudian awig-awig yang sudah disahkan di daftarkan oleh Prajuru Desa Adat ke perangkat daerah provinsi yang membidangi urusan Desa Adat. Pedoman yang dimaksud dari hasil seminar awig-awig I adalah yang berhubungan dengan dasar pokok penulisan awig-awig. Sesuai dengan ajaran Tri Hita Karana semua komponen masyarakat dalam bertindak diharapkan harus berpatokan pada konsep Tri Hita Karana (Astiti, 2010). Pada tahun 2019 terbentuk Peraturan Daerah Nomor 4 Tahun 2019 tentang desa adat di Bali menggantikan Peraturan Daerah Nomor 3 Tahun 2001. Perubahan yang terdapat dalam Peraturan Daerah Nomor 4 tahun 2019 hanya terletak pada desa pakraman yang sekarang disebut desa adat. Awig-awig pada desa adat berisikan kaidah dan acuan yang bertujuan untuk memeperoleh ketentraman dalam hidup bermasyarakat yang di dalamnya terdapat juga sanksi- sanksi bagi siapa saja yang melakukan pelanggaran. Adapun dasar dibentuknya Peraturan Daerah Nomor 4 Tahun 2019 terdapat pada bagian menimbang, yaitu: Desa adat di Bali yang sudah bekembang dan tumbuh yang dimana memilki hak tradisional, hak asal usul dan hak otonomi asli mengatur rumah tangganya sendiri, dimana itu semua sudah memberikan peranan besar terhadap kelangsungan hidup bermasyarakat. Poin berikutnya, desa adat merupakan satu kesatuan masyarakat hukum adat yang ada di Bali yang berpijak pada teori Tri Hita Karana dengan tercermin dari ajaran agama Hindu dan nilai budaya kearifan lokal, dimana ajaran agama dan budaya memilki fungsi ataupun arti yang amat penting dalam pembangunan dan perkembangan bermasyarakat dan negara. Digantinya Peraturan Daerah Nomor 3 Tahun 2001 sebagaimana telah diubah menjadi Peraturan Daerah Nomor 4 Tahun 2019 dikarenakan peraturan tersebut sudah tidak relevan lagi dengan perkembangan hukum saat ini. Maka dari penjabaran diatas dirasa perlu membentuk Peraturan Daerah tentang Desa Adat baru yang dituangkan dalam Peraturan Daerah Nomor 4 Tahun 2019.

Penulisan awig-awig memilki dua arti yang pertama adalah menuliskan awig-awig yang sudah ada untuk dikoreksi selaras dengan keadaan saat ini. Yang kedua adalah menuliskan awig-awig yang sudah ada tetapi masih dalam bentuk tidak tertulis untuk dijadikan awig-awig tertulis. Pada saat ini awig-awig tertulis menjadi penting dalam memberi pertanggungan kepastian hukum dan juga dapat memudahkan prajuru desa dalam memproses kasus-kasus adat. Tujuan dari dilaksanakannya penulisan awig-awig ini antara lain untuk menuliskan norma hukum ada yang dimana sebelumnya norma tersebut tidak tertulis, adanya kejelasan hukum bagi krama desa, dijadikan warisan bagi generasi mendatang. Manfaat dari adanya awig-awig tertulis berupa memudahkan untuk melaksanakan tujuan desa adat, memudahkan krama desa adat untuk mempelajari awig-awig yang ada, memudahkan untuk menganalisisawig-awig dan memudahkan krama desa setempat untuk mempertahankan ajaran agama hindu dan mewujudkan teori Tri Hita Karana. Bila dibandingkan awig-awig tertulis dengan awig-awig tidak tertulis, tentu terdapat kelebihan dan kelemahannya. Kelemahan dari awig-awig tidak tertulis menjadi kelebihan dari awigawig tertulis. Sedangkan kelemahan awig-awig tertulis menjadi kelebihan dari awig-awigtidak tertulis. Kelebihan dari awig-awig tertulis adalah lebih menjamin kejelasan hukum, lebih cepat dan mudah untuk dipelajari ataupun dimengerti dan lebih sederhana untuk diterapkan, kemudian 
kelebihan dari awig-awig tidak tertulis ialah antara lain lebih fleksibel maka relatif lebih gampang untuk menyamakan dengan perkembangan saat ini.

\section{Pengesahan Awig-Awig berdasarkan Peraturan Daerah Nomor 4 Tahun 2019}

Proses pengesahan awig-awig dilaksanakan setelah awig-awig dijadikan pedoman oleh krama desa adat. Tahap awal pada pengesahan awig-awig desa adat disahkannya awig-awig tertulis dalam paruman atau sangkepan desa adat, lalu dalam paruman tersebut diumumkan secara terbuka kepada krama desa adat setempat. Awig-awig yang sudah disahkan dalam paruman kemudian di daftarkan langsung oleh prajuru desa adat ke perangkat Pemerintah Provinsi yang membidangi urusan mengenai Desa Adat. Pengesahan awig-awig ini bermakna bahwa pemerintah sudah mendampingi dari tahapan awal penulisan hingga pengesahan awig-awig desa adat. Pendapingan yang dilakukan oleh instansi dari Dinas Kebudayaan bertujuan untuk menunjukan bahwa pemerintah mengetahui bagaimana proses dalam penulisan awig-awig desa adat. Setiap desa adat pasti memilki awig-awig walaupun bentuk dari awig-awig desa adat masih ada yang belum tertulis tetapi kecendrungan desa adat dalam menuliskan awig-awignya sudah dimulai sejak tahun 1969 yang bertujuan untuk memudahkan generasi mendatang dan prajuru desa adat untuk mengetahui isi awigawig desanya.

Awig-awig desa adat dibuat harus sesuai dengan keadaan objektif masing- masing desa adat agar dapat digunakan sebagai pedoman, kaidah atau norma oleh prajuru desa adat dalam menjalankan tanggung jawab ataupun tugas. Dalam pelaksanaan pengesahan awig-awig, hal yang paling pentingadalah adanya awig-awig tertulis itu sendiri yang sistematis dan sinkron yang telah disetujuai dan disepakati oleh krama desa setempat dalam paruman secara musyawarah mufakat. Awig-awig desa adat memudahkan desa adat dalam mencapai tujuannya yakni kebahagian desa secara sekala dan niskala. Awig-awig memilki legalitas yang sangat kuat dalam kehidupan bermasyarakat sebagai hukum yang tumbuh dan berkembang dari bawah secara sosiologis.

\section{SIMPULAN DAN SARAN}

\section{Simpulan}

Berdasarkan uraian di atas, dapat ditarik simpulan yaitu: mekanisme penulisan awig-awig terdiri dari empat tahapan. Tahapan pertama ialah tahap persiapan yang dimulai Dari menyusun agenda penulisan atau mervisi awig-awig yang telah ada. Tahap kedua ialah, menuliskan rancangan awigawig. Tahap ketiga, melaksanakan sosialisasi terhadap draf awig-awig yang telah ada. Kemudian tahapan terakhir adalah menyelesaikan penulisan awig-awig. Tujuan dari dilaksanakannya penulisan awig-awig ini antara lain untuk menuliskan norma hukum ada yang dimana sebelumnya norma tersebut tidak tertulis, adanya kejelasan hukum bagi krama desa, dijadikan warisan bagi generasi mendatang. Adapun tahapan penulisan awig-awig, yaitu: mengadakan rapat bagi krama desa setempat untuk mengenali apa saja masalah dan bahan apa saja yang diperlukan dalam penulisan. Kemudian, membentuk panitia yang biasa disebut panitia kecil terdiri dari pemuka masyarakat yang bertugasuntuk menyusun dan menginterpretasikan segala permasalahan. Jika diperlukan panitia kecil dapat di dampingi oleh tim dari Pemerintah Daerah. Dalam parumankrama desa adat setempat konsep awig-awig yang diajukan bertujuan untuk mendapatkan pengkajian sampai diperoleh keputusan dari seluruk krama. Dalam pembuatan konsep awig-awig panitia kecil perlu mengadakan pembagian tugas. Proses pengesahan awig-awig dilaksanakan setetlah awig-awig dijadikan pedoman oleh krama desa adat. Tahap awal pada pengesahan awig-awig desa adat disahkannya awig-awig tertulis dalam paruman atau sangkepandesa adat, lalu dalam paruman tersebut diumumkan secara terbuka kepada krama desa adat setempat. Awig-awig yang sudah disahkan dalam paruman kemudian di daftarkan langsung oleh prajuru desa adat ke perangkat Pemeritah Provinsi yang membidangi urusan mengenai Desa Adat. Proses terakhir dari pengesahan awig-awig adalah pengesahan yang dilakukan secara niskala pada hari baik yang biasa disebut dengan pasupati atau pemlaspasanawig-awig

\section{Saran}

Berdasarkan hasil penelitian yang telah dijabarkan di atas, di sarankan beberapa hal yakni perlu mengkaji lebih mendalam agar awig-awig yang dibuat dapat sesuai dengan kehidupan krama desa adat setempat dan awig-awig yang ada harua sesuai dengan desa mawacara dan dharma agama desa 
adat/banjar adat masing-masing dan berpedoman pada konsep Tri Hita Karana. Kemudian, penulisan dan pengesahan awig-awig bertujuan untuk meningkatkan efektifitas awig-awig maka perlu dilakukan sinergitas dengan peraturan tertulis dalam hukum negara.

\section{DAFTAR PUSTAKA}

Astiti, T. I. P. (2005). Pemberdayaan Awig-Awig Menuju Ajeg Bali. Lembaga Dokumentasi dan Pubikasi Hukum Universitas Udayana.

Astiti, T. I. P. (2010). Desa Adat Menggugat dan Digugat. Udayana University Press.

Ida Bagus Nyoman Gandi Aditya, Parwata, A. G. O., \& Jayantiari, I. G. A. M. R. (2017). Implementasi Hak dan Kewajiban Pengusaha Pendatang (di Desa Pakraman Tengkulak Kaja Kecamatan Sukawati Kabupaten Gianyar). 4(2), 1-14.

Nadir, S. (2013). Otonomi Daerah dan Desentralisasi Desa: Menuju Pemberdayaan Masyarakat Desa. Jurnal Politik Profetik, l(1), 2013.

Parimartha, I. G. (2013). Silang Pandang Desa Adat dan Desa Dinas di Bali. Udayana University Press.

Purana, I. M. (2016). Pelaksanaan Tri Hita Karana dalam Kehidupan Umat Hindu. Jurnal Kajian Pendidikan Widya Accarya FKIP Universitas Dwijendra, 5(1), 67-76.

Sanjaya, D. B., \& Sugiartha, W. (2013). Harmonisasi, Integrasi Desa Pakraman dengan Desa Dinas yang Multietnik dan Multiagama Menghadapi Pergeseran, Pelestarian, dan Konflik di Bali. Jurnal Ilmu Sosial Dan Humaniora, 2(2), 265-274.

Sirtha, I. N. (2008). Aspek Hukum Dalam Konflik Adat di Bali. Udayana University Press.

Sudantra, K., \& dkk. (2011). Penuntun Penyuratan Awig-Awig, Contoh Awig-Awig Tertulis Desa Pakraman Tanah Aron Kabupaten Karangasem. Udayana University Press.

Wiryawan, I. W. G., Ketut Sukawati Lanang P. Perbawa, \& Wiasta, I. wayan. (2015). Hukum Adat Bali di Tengah Modernisasi Pembangunan dan Arus Budaya Global. Jurnal Bakti Saraswati, $4(2), 75754$. 